Annals of Warsaw University of Life Sciences - SGGW

Land Reclamation No 45 (2), 2013: 207-216

(Ann. Warsaw Univ. of Life Sci. - SGGW, Land Reclam. 45 (2), 2013)

\title{
Undrained shear strength of the heavily consolidated clay
}

\author{
JOANNA STRÓŻYK, MATYLDA TANKIEWICZ \\ Institute of Geotechnology and Hydrotechnology, Wroclaw University of Technology
}

\begin{abstract}
Undrained shear strength of the heavily consolidated clay. The undrained shear strength $\left(c_{u}\right)$ is considered one of the most basic parameter characterizing soils in engineering practice. The particular importance of $c_{u}$ is in the case of clayey soil. This parameter also is the basis for the classification of soil according to the ISO standard. The undrained shear strength usually is determined from unconfined compression test or from triaxial compression test. In the simple way it can be estimated from the fall cone penetrometer test as index parameter. In the presented work the results of unconfined compression tests for very stiff, heavily consolidated clay were shown. All analysed clay specimens were taken from the large depth, up to $303 \mathrm{~m}$ below terrain level. The tests results: undrained shear strength $\left(c_{u}\right)$ and unconfined compression strength $\left(q_{u}\right)$ were discussed in the relation on in situ consolidation stress, Atterberg's limits and the indicatory test - fall cone test results.
\end{abstract}

Key words: clay, heavily consolidated clay, undrained shear strength, fall cone test, unconfined compression test

\section{INTRODUCTION}

The paper presents the results of laboratory undrained shear strength of the Tertiary clays and silty clays from the Lower Silesia region. The samples were taken from boreholes drilled up to $303 \mathrm{~m}$ deep, on which depth the averaged vertical effective stress can be estimated at about $6 \mathrm{MPa}$.

The geotechnical properties of soils from a great depths (below $30 \mathrm{~m}$ deep) are of particular interest in the design of underground infrastructure: deep tunnels, underground mining, tube tunnels (Wright 2012). The geotechnical identification of the deep subgrade is also required in the design of new technologies in the energy and environmental engineering in the design of underground waste reservoirs.

The experiences in the testing of samples of soil taken from great depths are few and far. This is achieved by first of all the considerable cost of sampling, but also the difficulties arising from the sampling quality. The shear strength is considered as one of the basic soils parameter which determines the bearing capacity and stability of soil. In the case of clayey soil, especially at great depths occuring in the form of continuous layers, the water filtration conditions are very impeded. In a such conditions the basic parameter of soil shear strength can be considered: undrained shear strength - $c_{u}$ (Atkinson 2010, Wright 2012).

In the paper the results of laboratory tests of the $c_{u}$ parameter determined from unconfined compression test and from indicatory test - fall cone test are presented.

The values of $c_{u}$ from unconfined compression test were compared with soil depth and average effective vertical stress in situ $-\sigma^{\prime}{ }_{v o}$. The normalized 
undrained shear strength $\left(c_{u} / \sigma^{\prime}{ }_{v o}\right)$ were estimated and as noticed some soil samples showed a significant infringement of the soil structure. The disturbed soil samples were removed from the final analysis.

The calculation of index values of $c_{u}$ from fall cone test were done by according as proposed by Hansbo (1957) and the specification of PKN-CEN ISO/ /TS 17892:2009. The correction factors $(\mu)$ to determine corrected value of undrained shear strength $\left(c_{u(c o r r)}\right)$ from indicatory test were used. The proposition of correction factor to determine the $c_{u(c o r r)}$ from fall cone test for clayey soil with great depth were done.

\section{MATERIAL AND METHODS}

The laboratory tests were carried out on the tertiary soil samples taken from Lower Silesia area. The total of 24 samples were chosen. The undisturbed soil samples were collected from boreholes with depths ranging $18.5-303.0 \mathrm{~m}$ below terrain level. The study of basic geotechnical parameters soil were made in accordance with the PKN-CEN ISO/ /TS 17892:2009. The liquid limit $\left(w_{L}\right)$ was determined by fall cone penetrometer test, the cone angle was of 30 degrees (Head and Epps 2011).

The grain size distribution tests shown that examined soil are generally clays $(\mathrm{Cl})$ and silty clays $(\mathrm{siCl})$. The soil samples were characterized by high bulk densities $(\rho)$ from 1.9 to $2.2 \mathrm{t} / \mathrm{m}^{3}$, natural water content $\left(w_{n}\right)$ from 12.5 to $27.0 \%$. The Atterberg's limits were set: the plastic limit values $\left(w_{p}\right)$ ranged from 16.4 to $29.1 \%$ and the liquid limit $\left(w_{L}\right)$
38.4-96.2. Most of the soil occurred in stiff consistency $-I_{c}>1$, except one sample - in hard plastic consistency (PN EN ISO 14688:2006).

The undrained shear strength tests were carried out using two methods: the unconfined compression test and comparative, indicatory test using the fall cone penetrometer (Atkinson 2010, Head and Epps 2011). The unconfined compression test was carried out on samples with a diameter of $38 \mathrm{~mm}$ and a height of $76 \mathrm{~mm}$. The samples were compressed with axial rate of displacement of $2.4 \mathrm{~mm} / \mathrm{h}$. From researching the maximum value of the vertical stress at which the sample has been failed was read, this stress is considered to be the compressive strength in uniaxial stress state $\left(q_{u}\right)$. The undrained shear strength was calculated from the formula (PKN-CEN ISO/TS 17892:2009):

$c_{u}=0.5 \cdot q_{u}$

The indicatory tests of undrained shear strength $\left(c_{u}\right)$ was conducted by fall cone penetrometer with an electronic reading system and electromagnetic release system. The cone with an apex angle of 30 degrees were used. The cone mass was about $2,820 \mathrm{~g}$, this ensure the cone fall about $4 \mathrm{~mm}$ deep. During the study cone fell freely for $5 \mathrm{~s}$ in a sample of undisturbed soil, with a diameter of $80 \mathrm{~mm}$ and a height of about $100 \mathrm{~mm}$. After $5 \mathrm{~s}$, the reading of the cone position was performed. As shown Hansbo (1957) and Houlsby (1982), the $c_{u}$ value is directly proportional to the mass of cone $(\mathrm{m})$ and inversely proportional to the square of the value of the cone penetration $\left(i^{2}\right)$. The $c_{u}$ value can be determined from the relationship: 
$c_{u}=\mathrm{c} \cdot g \cdot \frac{m}{i^{2}}$

where:

$c_{u}$ - undrained shear strength $[\mathrm{kPa}]$,

$\mathrm{c}-$ constant depending on soil state and cone apex angle [-],

$g-$ gravity acceleration $\left[\mathrm{m} / \mathrm{s}^{2}\right]$,

$m$ - cone mass [g],

$i$ - cone penetration [mm].

The analysis assumes a constant $c=0.8$, proposed by Hansbo (1957) and 0.8 or 1.0 proposed by PKN-CEN ISO/ /TS 17892:2009 for the natural soil and the cone angle apex of 30 degrees, depending on local experience. The obtained results should be corrected for correction factor $(\mu)$, recommended by the PKN-CEN ISO/TS 17892:2009 and dependent on the liquid limit $\left(w_{L}\right)$. Finally the value of $c_{u \text { (corr) }}$ should be determined as:

$c_{u(\text { corr })}=\mu \cdot c_{u}$

where: $\mu=\left(\frac{0.43}{w_{L}}\right)^{0.45}$

\section{RESULTS AND DISCUSSION}

The test results of the basic soil parameters summarized in Table 1.

The results of the unconfined compression strength $\left(q_{u}\right)$ and the calculated undrained shear strength $\left(c_{u}\right)$ are shown in Table 2 . The values of strength $q_{u}$ vary in the range of $62.1 \div 1,006.2 \mathrm{kPa}$. The values of strength $c_{u}$ calculated from the formula (1) are respectively $31.0 \div 503.1 \mathrm{kPa}$.

Figure 1 shows the relationship between the obtained value $c_{u}$ and natural water content $\left(w_{n}\right)$, plastic limit $\left(w_{P}\right)$ and liquid limit $\left(w_{L}\right)$. The correlation between the $c_{u}, w_{n}$ and Atterberg's limits were observed repeatedly to soil in a plastic consistency (Sheahan et al. 1996, Santagata et al. 2005). There wasn't noted such correlation when analyzed heavily consolidated soil, taken from great depths. Probably a heavily consolidation of soil partially blurred the effect of Atterberg's limits of its undrained shear strength.

The test results according the soil depth (see Fig. 2) were shown. The vertical effective stress in situ $-\sigma^{\prime}{ }_{v o}$ increases with the depth and soil becomes more and more consolidated. So along with sampling depth we expect soil strength parameters $q_{u}$ and $c_{u}$ will be increased. This clear link to the analyzed soil is easy to see in soil with higher plasticity index $\left(I_{p}\right)$, when $I_{p}>30 \%$, and is very difficult to see in soil with lower $I_{p}$ - see Figure 2.

The several soil samples (Table 2) in a very clear manner different from that principle. These differences, as noted during the research, were joined with cracking of soils samples. The cracks could be the result of previous geological processes but also, more likely due to the strong decompression of soil sample out of the probe in the laboratory. Unfortunately, these cracks strongly affect obtained strength values $c_{u}$ (Table 2, Fig. 2), causing in some cases evident and in other underestimating the value of $c_{u}$.

In order to eliminate from analysis soil samples with significantly disturbed structure the normalization of $c_{u}$ parameter with effective stress in situ $-\sigma^{\prime}{ }_{v o}$ where done. In Table 2 the values of $c_{u}$ l $/ \sigma^{\prime}{ }_{v o}$ were shown. The soil samples with low value of normalized undrained shear strength $\left(c_{u} / \sigma^{\prime}{ }_{v o}\right)$ - below 0.05 - has been 
TABLE 1 . The soil sample characteristic: depth $(z)$, bulk density $(\rho)$, natural water content $\left(w_{n}\right)$, plastic limit $\left(w_{P}\right)$, liquid limit $\left(w_{L}\right)$, plasticity index $\left(I_{p}\right)$, consistency index $\left(I_{c}\right)$

\begin{tabular}{|c|c|c|c|c|c|c|c|c|c|}
\hline \multirow{2}{*}{ No } & \multirow{2}{*}{ Sample } & $\begin{array}{c}\text { Soil } \\
\text { symbol }\end{array}$ & $z$ & $\rho$ & $w_{n}$ & $w_{p}$ & $w_{L}$ & $I_{p}$ & $I_{c}$ \\
\hline & & ISO & m.b.t.* & $\mathrm{g} / \mathrm{cm}^{3}$ & $\%$ & $\%$ & $\%$ & - & - \\
\hline 1 & A1 & $\mathrm{Cl}$ & 47.5 & 2.2 & 15.7 & 17.3 & 48.9 & 31.6 & 1.1 \\
\hline 2 & $\mathrm{~A} 2$ & $\mathrm{Cl}$ & 63.5 & 2.1 & 22.9 & 26.5 & 96.2 & 69.7 & 1.1 \\
\hline 3 & $\mathrm{~A} 3$ & $\mathrm{Cl}$ & 74.5 & 2.1 & 17.1 & 16.4 & 38.4 & 22.0 & 1.0 \\
\hline 4 & A5 & $\mathrm{siCl}$ & 123.5 & 2.0 & 24.3 & 24.4 & 66.5 & 42.1 & 1.0 \\
\hline 5 & A11 & $\mathrm{siCl}$ & 287.5 & 2.0 & 27.0 & 30.3 & 66.3 & 36.0 & 1.1 \\
\hline 6 & $\mathrm{~B} 1$ & $\mathrm{CL}$ & 18.5 & 2.1 & 22.2 & 27.6 & 68.1 & 40.5 & 1.1 \\
\hline 7 & $\mathrm{~B} 2$ & $\mathrm{Cl}$ & 30.5 & 2.1 & 18.7 & 24.4 & 61.5 & 37.1 & 1.2 \\
\hline 8 & B3 & $\mathrm{siCl}$ & 47.2 & 2.2 & 20.0 & 20.3 & 51.2 & 30.9 & 1.6 \\
\hline 9 & B4 & $\mathrm{Cl}$ & 54.5 & 2.0 & 26.6 & 27.7 & 83.8 & 56.1 & 1.0 \\
\hline 10 & B5 & $\mathrm{Cl}$ & 79.5 & 2.0 & 28.2 & 29.1 & 91.3 & 62.2 & 1.0 \\
\hline 11 & B8 & $\mathrm{Cl}$ & 209.0 & 2.0 & 22.1 & 22.4 & 49.9 & 27.5 & 1.0 \\
\hline 12 & B12 & $\mathrm{Cl}$ & 291.5 & 2.1 & 19.7 & 25.0 & 53.1 & 28.1 & 1.2 \\
\hline 13 & B13 & $\mathrm{siCl}$ & 303.0 & 2.1 & 22.1 & 24.0 & 55.2 & 31.2 & 1.1 \\
\hline 14 & $\mathrm{C} 2$ & $\mathrm{Cl}$ & 24.3 & 2.2 & 19.9 & 27.0 & 64.1 & 37.1 & 1.2 \\
\hline 15 & $\mathrm{C} 3$ & $\mathrm{Cl}$ & 34.4 & 2.1 & 22.6 & 23.5 & 55.6 & 32.1 & 1.0 \\
\hline 16 & $\mathrm{C} 4$ & $\mathrm{Cl}$ & 54.0 & 2.1 & 22.5 & 22.0 & 67.6 & 45.6 & 1.0 \\
\hline 17 & $\mathrm{C} 5$ & $\mathrm{siCl}$ & 86.5 & 1.9 & 19.9 & 25.2 & 42.4 & 17.2 & 1.3 \\
\hline 18 & C6 & $\mathrm{Cl}$ & 88.5 & 2.0 & 24.4 & 26.4 & 59.2 & 32.8 & 1.1 \\
\hline 19 & $\mathrm{C} 7$ & $\mathrm{siCl}$ & 97.5 & 2.0 & 22.2 & 21.3 & 57.3 & 36.0 & 1.0 \\
\hline 20 & $\mathrm{C} 8$ & $\mathrm{siCl}$ & 103.5 & 2.0 & 17.6 & 24.7 & 49.8 & 25.1 & 1.3 \\
\hline 21 & $\mathrm{C} 10$ & $\mathrm{siCl}$ & 244.0 & 2.2 & 12.5 & 19.9 & 45.3 & 25.4 & 1.3 \\
\hline 22 & $\mathrm{C} 13$ & $\mathrm{Cl}$ & 261.5 & 1.9 & 24.4 & 22.1 & 43.0 & 20.9 & 0.9 \\
\hline 23 & $\mathrm{C} 12$ & $\mathrm{Cl}$ & 247.5 & 2.0 & 22.4 & 26.3 & 59.7 & 33.4 & 1.1 \\
\hline 24 & $\mathrm{C} 14$ & $\mathrm{siCl}$ & 289.5 & 2.0 & 22.1 & 25.1 & 60.3 & 35.2 & 1.1 \\
\hline
\end{tabular}

*Meters below terrain level.

removed from further analysis (as a disturbed samples). As shown on Figure 3 in the majority of these were sample with $I_{p}<30 \%$. Regarding with the above the further analysis were done on samples with $I_{p}>30 \%$ and $c_{u} / \sigma^{\prime}{ }_{v o}>0.05$.

The results of index test of undrained shear strength $\left(c_{u}\right)$ made by fall cone test - Table 3, strongly deviate from the ex- pected. The values of $c_{u}$ calculated from equation (2), and corrected strength values $\left(c_{u(c o r r)}\right)$ calculated from equation (3) using factor $c=1$ are often as much as almost 20-fold higher than the values obtained from unconfined compression test (Tables 2 and 3). Despite the foregoing, the $c_{u(c o r r)}$ values seems to be overestimated. It can be assumed that the inter- 
TABLE 2. Unconfined compression test results: depth $(z)$, average vertical effective stress in situ $\left(\sigma^{\prime}{ }_{v o}\right)$, unconfined compression strength $\left(q_{u}\right)$, undrained shear strength $\left(c_{u}\right)$, normalized undrained shear strength $\left(c_{u} / \sigma^{\prime}{ }_{v o}\right)$

\begin{tabular}{|c|c|c|c|c|c|c|c|}
\hline \multirow{2}{*}{ No } & \multirow{2}{*}{ Sample } & Soil symbol & $z$ & $\sigma_{v o}^{\prime}$ & $q_{u}$ & $c_{u}$ & $c_{u} / \sigma_{v o}^{\prime}$ \\
\cline { 3 - 8 } & & $\mathrm{ISO}$ & $\mathrm{m}$. b.t. $^{*}$ & $\mathrm{kPa}$ & $\mathrm{kPa}$ & $\mathrm{kPa}$ & - \\
\hline 1 & $\mathrm{~A} 1$ & $\mathrm{Cl}$ & 47.5 & 940.5 & 442.7 & 221.4 & 0.24 \\
\hline 2 & $\mathrm{~A} 2$ & $\mathrm{Cl}$ & 63.5 & 1257.3 & 193.4 & 96.7 & 0.08 \\
\hline 3 & $\mathrm{~A} 3$ & $\mathrm{Cl}$ & 74.5 & 1475.1 & 118.4 & 59.2 & 0.04 \\
\hline 4 & $\mathrm{~A} 5$ & $\mathrm{siCl}$ & 123.5 & 2445.3 & 278.0 & 139.0 & 0.06 \\
\hline 5 & $\mathrm{~A} 11$ & $\mathrm{siCl}$ & 287.5 & 5692.5 & 659.6 & 329.8 & 0.06 \\
\hline 6 & $\mathrm{~B} 1$ & $\mathrm{CL}$ & 18.5 & 366.3 & 200.9 & 100.4 & 0.27 \\
\hline 7 & $\mathrm{~B} 2$ & $\mathrm{Cl}$ & 30.5 & 603.9 & 199.0 & 99.5 & 0.16 \\
\hline 8 & $\mathrm{~B} 3$ & $\mathrm{siCl}$ & 47.2 & 934.6 & 223.0 & 111.5 & 0.12 \\
\hline 9 & $\mathrm{~B} 4$ & $\mathrm{Cl}$ & 54.5 & 1079.1 & 338.2 & 169.1 & 0.16 \\
\hline 10 & $\mathrm{~B} 5$ & $\mathrm{Cl}$ & 79.5 & 1574.1 & 297.9 & 149.0 & 0.09 \\
\hline 11 & $\mathrm{~B} 8$ & $\mathrm{Cl}$ & 209.0 & 4138.2 & 719.4 & 359.7 & 0.09 \\
\hline 12 & $\mathrm{~B} 12$ & $\mathrm{Cl}$ & 291.5 & 5771.7 & 1006.2 & 503.1 & 0.09 \\
\hline 13 & $\mathrm{~B} 13$ & $\mathrm{siCl}$ & 303.0 & 5999.4 & 782.8 & 391.4 & 0.07 \\
\hline 14 & $\mathrm{C} 2$ & $\mathrm{Cl}$ & 24.3 & 481.1 & 266.5 & 133.3 & 0.28 \\
\hline 15 & $\mathrm{C} 3$ & $\mathrm{Cl}$ & 34.4 & 681.1 & 278.5 & 139.2 & 0.20 \\
\hline 16 & $\mathrm{C} 4$ & $\mathrm{Cl}$ & 54.0 & 1069.2 & 218.7 & 109.4 & 0.10 \\
\hline 17 & $\mathrm{C} 5$ & $\mathrm{siCl}$ & 86.5 & 1712.7 & 62.1 & 31.0 & 0.02 \\
\hline 18 & $\mathrm{C} 6$ & $\mathrm{Cl}$ & 88.5 & 1752.3 & 185.1 & 92.6 & 0.05 \\
\hline 19 & $\mathrm{C} 7$ & $\mathrm{siCl}$ & 97.5 & 1930.5 & 64.6 & 32.3 & 0.02 \\
\hline 20 & $\mathrm{C} 8$ & $\mathrm{siCl}$ & 103.5 & 2049.3 & 62.1 & 31.0 & 0.02 \\
\hline 21 & $\mathrm{C} 10$ & $\mathrm{siCl}$ & 244.0 & 4831.2 & 539.8 & 269.9 & 0.06 \\
\hline 22 & $\mathrm{C} 13$ & $\mathrm{Cl}$ & 261.5 & 5177.7 & 111.1 & 55.6 & 0.01 \\
\hline 23 & $\mathrm{C} 12$ & $\mathrm{Cl}$ & 247.5 & 4900.5 & 355.4 & 177.7 & 0.04 \\
\hline 24 & $\mathrm{C} 14$ & $\mathrm{siCl}$ & 289.5 & 5732.1 & 991.1 & 495.6 & 0.09 \\
\hline
\end{tabular}

*Meters below terrain level.

pretation of cone penetrometer tests that suggested Hansbo (1957) and Houlsby (1982) presented by equations $(2,3)$ for stiff heavily consolidated clays should be reexamined. Head and Epps (2011) reported that the relationship described by the equation (2) was tested using the cone of up to $400 \mathrm{~g}$. It can be assumed that the use of the fall cone penetrometer test to the estimation of undrained shear strength $\left(c_{u(c o r r)}\right)$ for heavily consolidated clays requires further research and determination appropriate correlation model.

The results of undrained shear strength determined from unconfined compressive test were correlated with $c_{u}$ with indicatory tests (fall cone test) see Figure 4. The correlation between this values for soil samples with $I_{p}>30 \%$ 


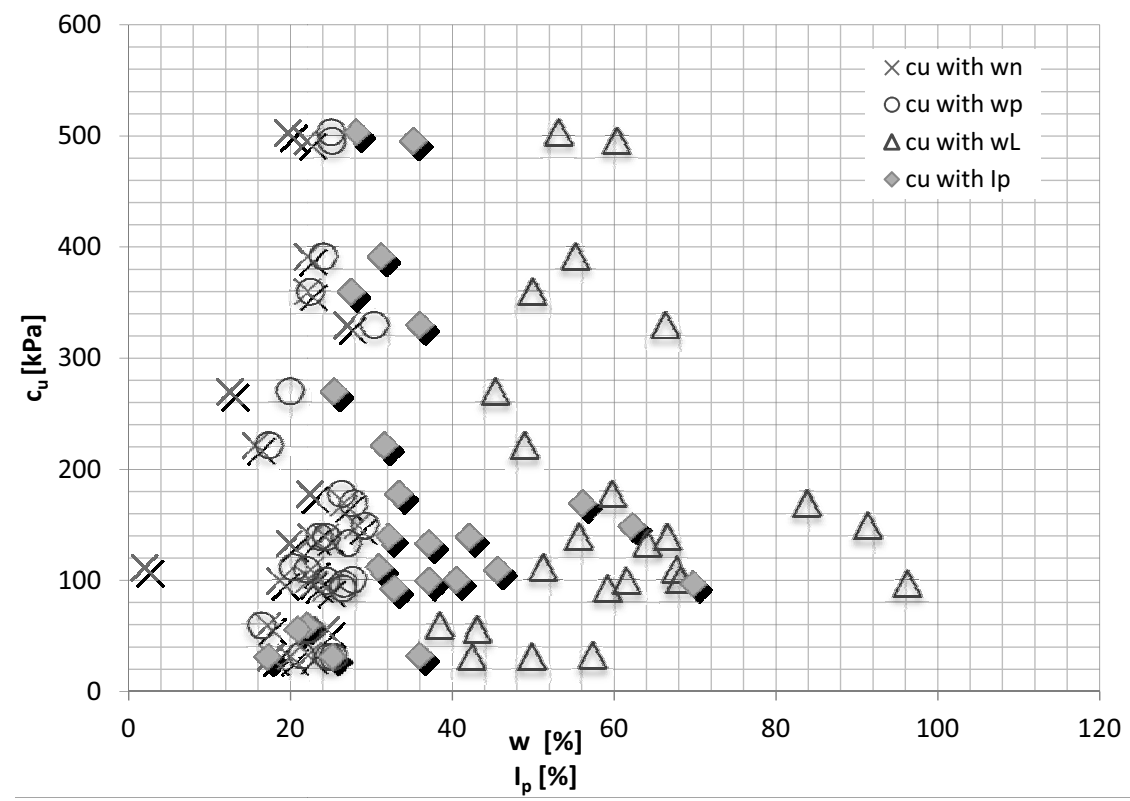

FIGURE 1. The results of uniaxial compression test: undrained shear strength $\left(c_{u}\right)$ with natural water content $\left(w_{n}\right)$, plastic limits $\left(w_{p}\right)$, liquid limits $\left(w_{L}\right)$, and plasticity index $\left(I_{p}\right)$

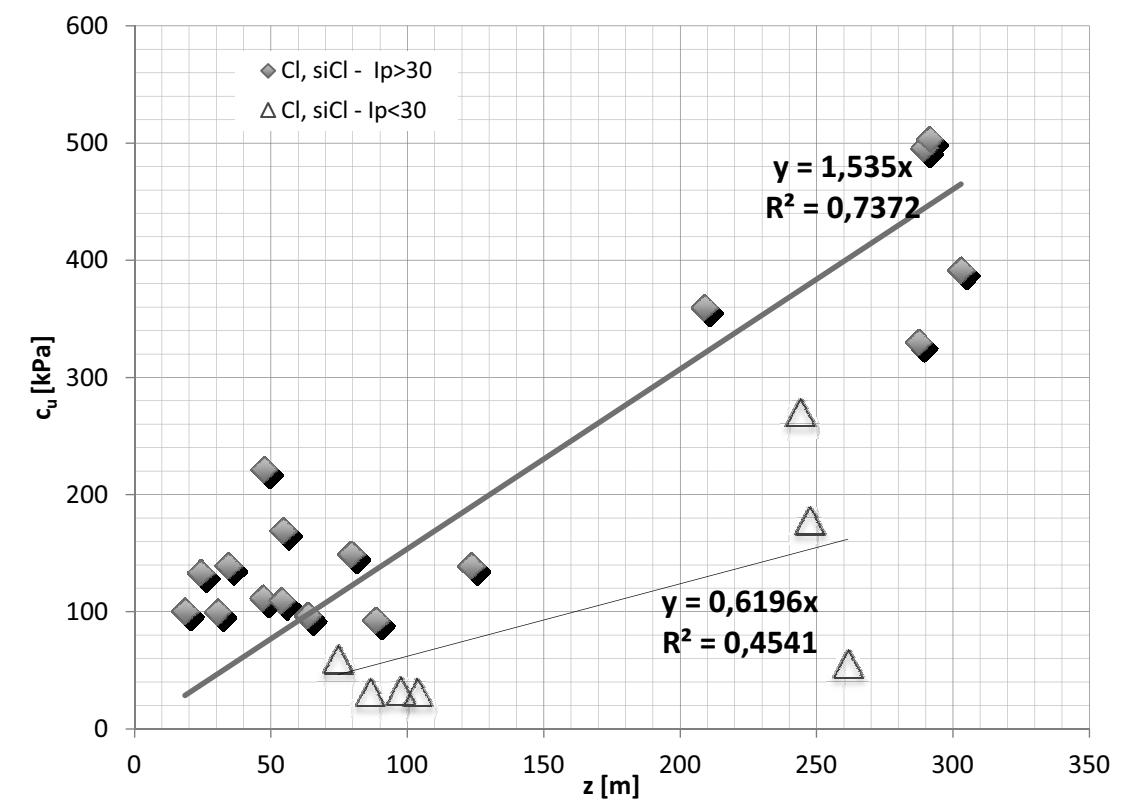

FIGURE 2. The results of unconfined compression test: undrained shear strength $\left(c_{u}\right)$ with depth $(z)$; $\mathrm{m}-$ meters below terrain level 


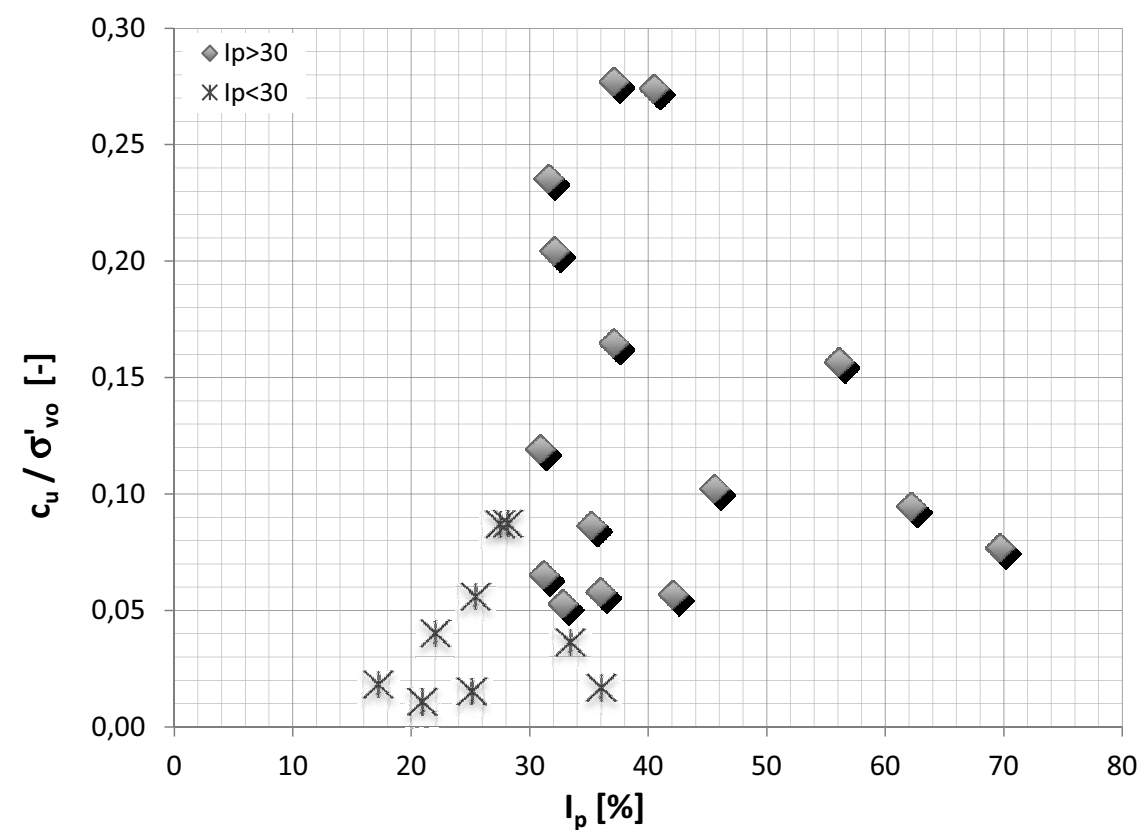

FIGURE 3 . The plasticity index $\left(I_{p}\right)$ with normalized undrained shear strength $\left(c_{u} / \sigma^{\prime}{ }_{v o}\right)$

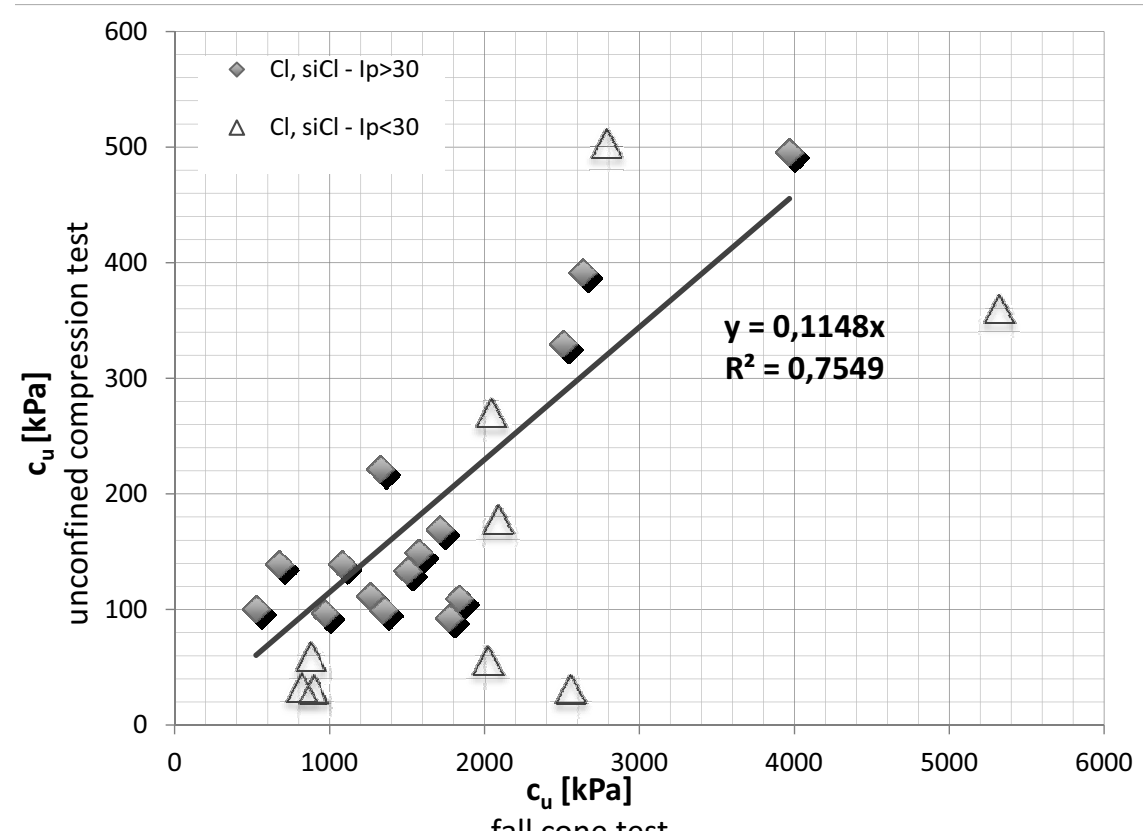

fall cone test

FIGURE 4. The undrained shear strength $\left(c_{u}\right)$ from unconfined compression test and fall cone test (The regression line represent correlation only for soil with $I_{p}>30 \%$ ) 
TABLE 3. The fall cone test results for selected soil samples: depth of cone fall $(i)$, correction factor $(\mu)$, calculated undrained shear strength $\left(c_{u}\right)$, corrected calculated undrained shear strength $\left(c_{u(c o r r)}\right)$

\begin{tabular}{|c|c|c|c|c|c|c|c|}
\hline \multirow{2}{*}{ No } & \multirow{2}{*}{ Sample } & Soil symbol & $i$ & $\mu$ & $c_{u}$ & $c_{u(\mathrm{corr})}$ & $13 \% c_{u(\mathrm{corr})}$ \\
\hline & & ISO & $\mathrm{mm}$ & - & $\mathrm{kPa}$ & $\mathrm{kPa}$ & $\mathrm{MPa}$ \\
\hline 1 & A1 & $\mathrm{Cl}$ & 4.56 & 0.963 & 1330.0 & 1281.2 & 166.6 \\
\hline 2 & $\mathrm{~A} 2$ & $\mathrm{Cl}$ & 5.34 & 0.710 & 969.9 & 689.0 & 89.6 \\
\hline 3 & $\mathrm{~A} 3$ & $\mathrm{Cl}$ & 5.61 & 1.074 & 878.8 & 943.8 & 122.7 \\
\hline 4 & A5 & $\mathrm{siCl}$ & 6.40 & 0.839 & 675.2 & 566.4 & 73.6 \\
\hline 5 & A11 & $\mathrm{siCl}$ & 3.32 & 0.840 & 2509.1 & 2107.6 & 274.0 \\
\hline 6 & B1 & $\mathrm{CL}$ & 7.25 & 0.830 & 526.2 & 436.7 & 56.8 \\
\hline 7 & B2 & $\mathrm{Cl}$ & 4.53 & 0.869 & 1347.7 & 1171.0 & 152.2 \\
\hline 8 & B3 & $\mathrm{siCl}$ & 4.68 & 0.944 & 1262.7 & 1191.5 & 154.9 \\
\hline 9 & B4 & $\mathrm{Cl}$ & 4.02 & 0.756 & 1711.4 & 1293.7 & 168.2 \\
\hline 10 & B5 & $\mathrm{Cl}$ & 4.19 & 0.727 & 1575.3 & 1145.8 & 149.0 \\
\hline 11 & B8 & $\mathrm{Cl}$ & 2.28 & 0.955 & 5320.2 & 5078.4 & 660.2 \\
\hline 12 & $\mathrm{~B} 12$ & $\mathrm{Cl}$ & 3.15 & 0.928 & 2787.2 & 2587.2 & 336.3 \\
\hline 13 & B13 & $\mathrm{siCl}$ & 3.24 & 0.912 & 2634.5 & 2403.1 & 312.4 \\
\hline 14 & $\mathrm{C} 2$ & $\mathrm{Cl}$ & 4.29 & 0.853 & 1502.7 & 1281.6 & 166.6 \\
\hline 15 & $\mathrm{C} 3$ & $\mathrm{Cl}$ & 5.06 & 0.909 & 1080.2 & 982.1 & 127.7 \\
\hline 16 & $\mathrm{C} 4$ & $\mathrm{Cl}$ & 3.88 & 0.833 & 1837.1 & 1529.7 & 198.9 \\
\hline 17 & $\mathrm{C} 5$ & $\mathrm{siCl}$ & 3.15 & 1.027 & 894.5 & 918.8 & 119.4 \\
\hline 18 & C6 & $\mathrm{Cl}$ & 3.95 & 0.884 & 1772.6 & 1566.8 & 203.7 \\
\hline 19 & $\mathrm{C} 7$ & $\mathrm{siCl}$ & 5.81 & 0.897 & 819.3 & 734.9 & 95.5 \\
\hline 20 & $\mathrm{C} 8$ & $\mathrm{siCl}$ & 3.29 & 0.955 & 2555.1 & 2441.2 & 317.4 \\
\hline 21 & $\mathrm{C} 10$ & $\mathrm{siCl}$ & 3.68 & 0.997 & 2042.2 & 2036.1 & 264.7 \\
\hline 22 & $\mathrm{C} 13$ & $\mathrm{Cl}$ & 3.70 & 1.021 & 2020.2 & 2061.9 & 268.1 \\
\hline 23 & $\mathrm{C} 12$ & $\mathrm{Cl}$ & 3.64 & 0.881 & 2087.3 & 1838.0 & 238.9 \\
\hline 24 & $\mathrm{C} 14$ & $\mathrm{siCl}$ & 2.64 & 0.877 & 3968.1 & 3478.5 & 452.2 \\
\hline
\end{tabular}

and $c_{u} / \sigma^{\prime}{ }_{v o}>0.05$ is quiet good $\left(\mathrm{R}^{2}=\right.$ $=0.75)$. In group of soil samples with $I_{p}<30 \%$ and $c_{u} / \sigma^{\prime}{ }_{v o}<0.05$ no correlation were observed.

Further analysis on sample with $I_{p}>$ $>30 \%$ and $c_{u} / \sigma_{v o}^{\prime}>0.05$ indicated that correction of the $c_{u}$ values by correction factor $-\mu$ (equation 3$), c_{u(c o r r)}$ lightly increase correlation between the $c_{u}$ values determined from both discussed tests $\left(\mathrm{R}^{2}\right.$ increased from 0.75 to 0.78$)$ - see Figure 5.

As the research shown the $c_{u}$ values from unconfined compression test were usually much lower, that from indicatory tests and were accounted for about 13\% of the $c_{u}$ value from indicatory test (see equation on Figure 5). 


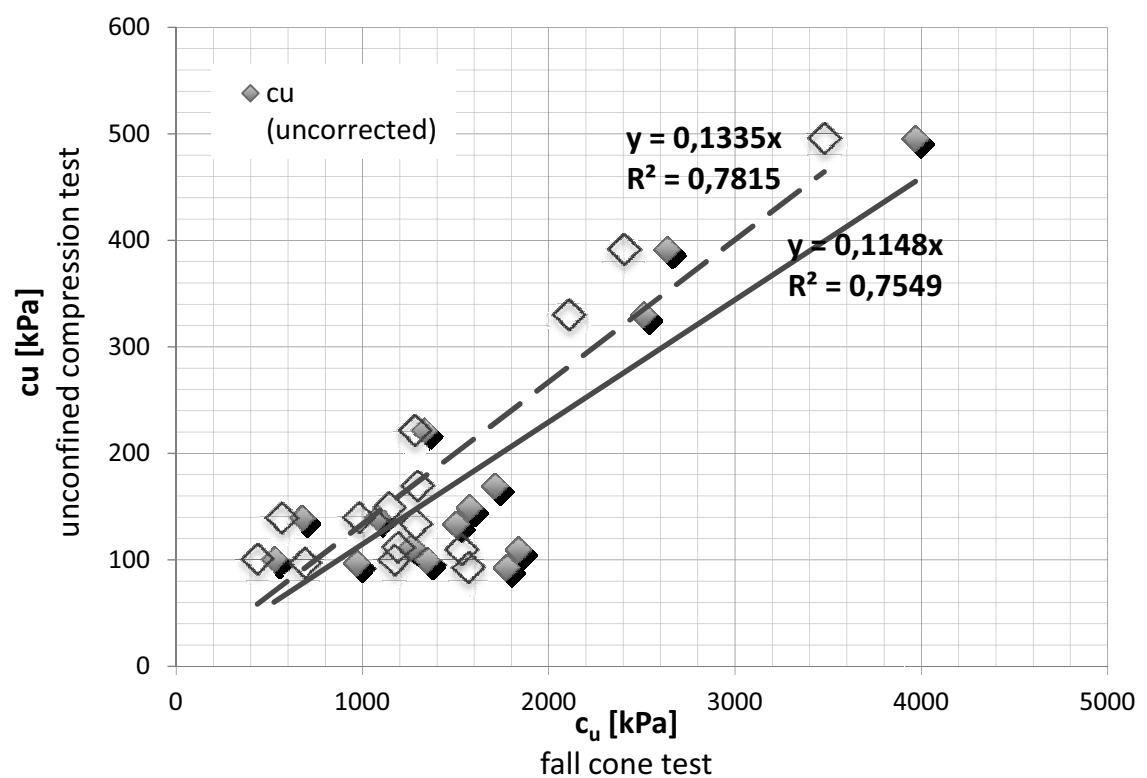

FIGURE 5. The undrained shear strength $\left(c_{u}\right)$ from unconfined compression test for soil with $I_{p}>30 \%$ with uncorrected and corrected undrained shear strength $\left(c_{u}\right)$ from fall cone test

\section{CONCLUSIONS}

The paper presents the results of the soil compression strength in unconfined stress condition, heavily consolidated, stiff clays and silty clays taken from great depth from the Lower Silesia region. The compression test results were used to determine the compressive strength $\left(q_{u}\right)$ and undrained shear strength $\left(c_{u}\right)$. The $c_{u}$ values was determined also by the indicatory test - fall cone penetrometer test, using the correlation recommended by PKN-CEN ISO/TS 17892:2009, Hansbo (1957).

The undrained shear strength values obtained from the unconfined compression test ranged $31.0 \div 658.0 \mathrm{kPa}$. Most of the samples collected from depths greater than $200 \mathrm{~m}$ showed the strength $c_{u}>300$ $\mathrm{kPa}$, which indicated that according the classification PN EN ISO 14688:2006 its should be qualify as weak rock. The results of indicatory undrained shear strength, performed on fall cone penetrometer and interpreted according to the equations $(2,3)$ by Hansbo (1957) and PKN-CEN ISO/TS 17892:2009, showed high values $c_{u(c o r r)}$ ranging from 3.8 to $11.13 \mathrm{MPa}$. The $c_{u}$ values obtained from unconfined compression test were much lower than from indicatory test, and were accounted for about $13 \%$ of the value first test.

The detailed analysis showed that some soil sample due to decompression lost its intact structure. The normalized values $c_{u} / \sigma^{\prime}{ }_{v o}$ were in that case extremely low. This phenomenon was observed in samples with a lower value $I_{p}\left(I_{p}<\right.$ $<30 \%$ ). Those samples (with $I_{p}<30 \%$ and $\left.c_{u} / \sigma^{\prime}{ }_{v o}<0.05\right)$ were excluded from further analysis. 
The correlation between the $c_{u}$ values and depth were observed in group of intact samples $\left(R^{2}=0.74\right)$. There were almost no correlation between $c_{u}$ and Atterberg's limits, caused probably due to heavy consolidation.

It is assumed that the relationship derived by Hansbo (1957) recommended by PKN CEN does not apply in the case of stiff heavily consolidated clays. The use of fall cone penetrometer to assess the undrained shear strength $\left(c_{u}\right)$ of consolidated clays from great deep requires further research and find the right correlation between the penetration of the cone, the mass, and strength $c_{u}$.

\section{REFERENCES}

ATKINSON J. 2010: The mechanics of soils and foundation. Taylor \& Francis, New York.

HANSBO S. 1957: A new approach to determination of the shear strength of clay by the fall-cone test. Proc. of the Royal Swedish geotechnical Institute 14.

HEAD K.H., EPPS R.J. 2011: Manual of soil laboratory testing. Vol. 2. Whittles, Dunbeath.

HOULSBY G.T. 1982: Theoretical analysis of the fall cone test. Géotechnique 32 (2): 111-118.

SANTAGATA M., GERMAINE J.T., LADD C.C. 2005: Factors Affecting the Initial Stiffness of Cohesive Soils. Journal of Geot. and Geoenv. Eng. 131 (4): 135-143.

SHEAHAN T., LADD C., GERMAINE J. 1996: Rate-Dependent Undrained Shear Behavior of Saturated Clay. J. Geotech. Eng. 122 (2): 346-359.

WRIGHT P.J. 2012: Validation of soil parameters for deep tube tunnel assessment, Proc. of the ICE - Geotechnical Engineering $166(1) ; 18-27$ :
PN-EN ISO 14688:2006. Badania geotechniczne. Oznaczanie i klasyfikowanie gruntów.

PKN-CEN ISO/TS 17892:2009. Badania geotechniczne. Badania laboratoryjne gruntów.

Streszczenie: Wytrzymałość na ścinanie bez odpływu silnie skonsolidowanych iłów. W pracy przedstawiono wyniki badań wytrzymałości na ściskanie $\left(q_{u}\right)$ i ścinanie w warunkach bez odpływu $\left(c_{u}\right)$ silnie skonsolidowanych iłów. Próby pobrano $\mathrm{z}$ otworów wiertniczych prowadzonych do głębokości $303 \mathrm{~m}$, wykonanych na terenie Dolnego Śląska. Badania wykonywano dwoma metodami: metodą ściskania w stanie jednoosiowego naprężenia oraz penetrometrem stożkowym. Wartość $c_{u}$ obliczano $\mathrm{z}$ badań penetrometrem, stosując zalecenia PKN-CEN ISO/TS 17892:2009. Wartości wytrzymałości $c_{u}$ uzyskane z testu ściskania wyniosły $31,0 \div 658,0 \mathrm{kPa}$. Wyniki badań wskaźnikowych wytrzymałości $c_{u}$ wykonane penetrometrem stożkowym wykazały nadzwyczaj duże wartości $c_{u \text { (corr) }} \mathrm{z}$ zakresu $3,8 \div 11,13 \mathrm{MPa}$. Zauważono, że zależność korelacyjna pomiędzy masą stożka, jego penetracją i wytrzymałością $c_{u}$, zalecana przez PKN CEN, nie ma zastosowania w przypadku zwartych silnie skonsolidowanych iłów. Stosowanie penetrometru stożkowego do oceny wytrzymałości $c_{u}$ zwartych skonsolidowanych iłów wymaga dalszych badań i znalezienia odpowiedniej korelacji pomiędzy penetracją stożka a jego masą i wytrzymałością $c_{u}$.

Stowa kluczowe: iły, silnie skonsolidowane iły, wytrzymałość na ścinanie bez odpływu, penetrometr stożkowy, jednoosiowe ściskanie

MS. received December 2013

\section{Authors' address:}

Politechnika Wrocławska Instytut Geotechnologii i Hydrotechnologii Wybrzeże Wyspiańskiego 27, 50-350 Wrocław

e-mail: Joanna.Strozyk@pwr.wroc.pl Matylda.Tankiewicz@pwr.wroc.pl 